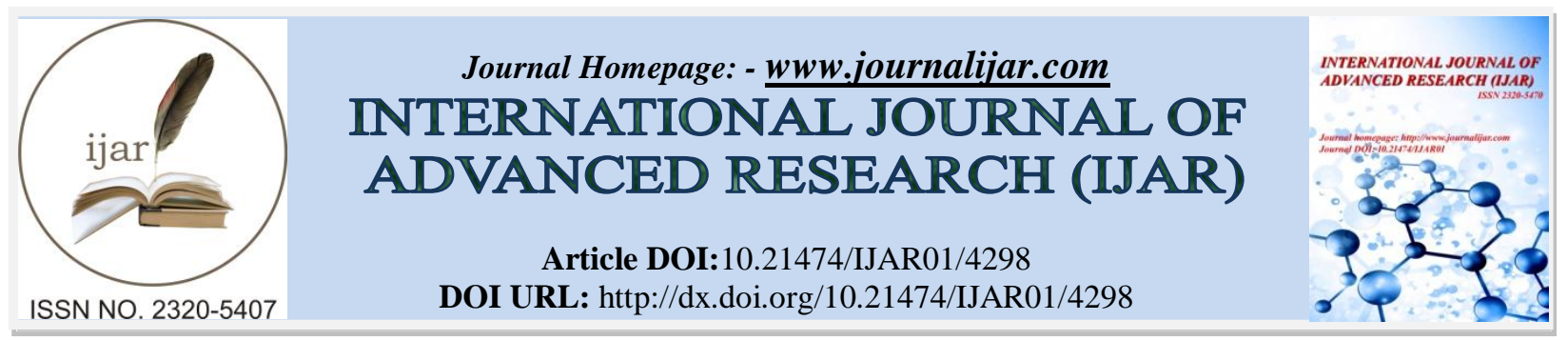

RESEARCH ARTICLE

\title{
AN ANALYTICAL STUDY OF MAIDAMS OF AHOM KINGS IN COMPARISON WITH EGYPTIAN PYRAMIDS.
}

Debojit Mitra.

Assistant Teacher, Doom Dooma Bangiya Vidyalaya, Doom DoomDist. Tinsukia, Assam, India.

\section{Manuscript Info}

Manuscript History

Received: 26 March 2017

Final Accepted: 27 April 2017

Published: May 2017

\section{Abstract}

Maidams of Ahom Kings in and around Charaideo are known as "The Pyramids of Assam". Both of the pyramids of Egypt and the Maidams of Ahom Kings in Assam were constructed for the same purpose burying the bodies of the departed kings and the belief regarding the custom behind those was also the same - the departed kings would become alive and live a royal life in the other world. The art and sculpture on the bodies of both of the monuments were wonderful and note worthy, but unfortunately the maidams have not got importance as world heritage comparing to pyramids which have been recognized as site of world heritage. The main objective of my project is to get the maidams focused abroad and let the people know about the history and significances of the maidams.

Copy Right, IJAR, 2017,. All rights reserved.

\section{Maidams:-}

The word "Maidam" is a Tai word which means tomb in English. It is the sacred burial ground of AhomKings (Swargadeo) and queens. Maidams are hemispherical in structure comprising a massive underground vault with one or more chambers having domical superstructure and covered by a heap of earthen mound. Though these are quite different in appearance from the pyramids of Egypt, the purpose of building these tombs is the same.

\section{Location of Maidams:-}

Though the maidams are scattered all around Sibsagar, Jorhat and Dibrugarh towns of upper Assam, most of the maidams of powerful kings of Ahom kingdom were found in and around the hillock of charaideo, a district town of Present day Assam. The name "Charaideo' comes from the Tai word - "Che Tam Doi" 'Che' means town, "Tam" means foot hill and "Doi" means hill or mountain. So, the word "Charaideo" means "town in the foot hill" Charaideo was the first capital of Ahom Kingdom established by the first Ahom Swargadeo Chao-Lung-Siu-ka-pha in 1228 A.D. The town is located 30 K.M. away to the east of Sibsagar town in upper Assam in the Sibsagar Sonari road. It is located at the foot hills of Nagaland. Charaideo is commonly known as the pyramids of Assam and it was the original Capital of the Ahom Kings. Though the capital of Ahom Kingdom moved many times, Charaideo remained the symbolic centre. It is also believed to be the place of ancestoral Gods of the Ahoms. Charaideo is also known as "Jerusalem of the East" for the location of maidams of the Ahom Kings, queens and the nobles.

\section{History of Maidams:-}

Before the reign of Swargadeo (King) Rudra Singha, the dead bodies of the members of Royal families were buried in Maidams instead of cremation. Transforming to Hinduism, Ahom Queen Phuleswari Devi (1722-1731 A.D.) 
abolished the custom of burial and started the custom of cremation of dead-bodies. Swargadeo Rudra Singha (16961714 A.D) introduced the Khel (a group of workers) of the khounds who were engaged to pay homage and perform all the rituals after cremation of dead bodies. From this it can be understood that during the reign of Rudra Singha the custom of cremation of the dead bodies of the Ahom Kings started instead of burying inside maidams. But the maidam of Rudra Singha's brother lechai Namrupia King was found at Na-Ali near Jorhat. In 1925, during the construction of Jorhat- Furkating railway track, the railway company had dug out the maidam and abolished it by the order of the British Government. According to Gait's "A History of Assam" the ashes of the dead body of king Rajeswar Singha (1769 A.D.) was taken to Charaideo and buried inside maidam after cremating by the Brahmaputra Some of the sub-tribes of the Tai-Ahoms still following the custom of burying in maidams. The actual number of maidams has exceeded 150, but only thirty of those have been protected by Archeological department of India and Assam state Archeological department and the remaining 120 maidams have been unprotected. Most of the unprotected maidams have been encroached by the local people and are so going to be damaged. The largest unprotected maidam is Bali Maidam at Nimona Gorh near Charaideo. The maidam is called Bali Maidam because while the British plundered it, they got obstruction from excess sand in the surroundings. Though most of the maidams are Scattered in the hillock of Charaideo, Some of them are also found at Nazira, Lakuwa, Dalbagan near Sibsagar and Jorhat. A few of them were also discovered inside the forests and tea-gardens of Namrup. The Bauli Maidam at Nazira is supposed to be the maidam of one of the powerful kings of the Ahoms, Around the foot hill of Charaideo, the maidams are scattered in rows covering a distance of more than three to four miles and then another row of maidams starts below the previous row. It is assumed that some of the maidams occupy about two or three acres of land. There are about 120 maidams in one such row. Recently four new maidams have been discovered in the locality backside of Dalbagan Higher Secondary School near Charaideo and one of them has been identified as the maidam of the first Ahom Swargadeo and founder of Ahom Dynasty Chao-Lung-Siu-Ka-Pha. The other three maidams are of Suo-Kang-Pha, Suobin-Pha and Suo-Tau-Pha (Pha is a Tai word which means' Lord). Some of the maidams are very high according to the power of the kings. The height of such maidams measures as high as two or three full grown beetel nut tree. In charaideo-burial ground, most of the maidams could not be identified yet except the maidams of Gadadhar Signha and Rudra Singha. The large maidams of Charaideo are thought to be linked with seventeenth to eighteenth century Ahom Kings Gadadhar Singha (1696 AD - 1714 AD) and their family members.

\section{Ancient History of Charaideo:-}

Charaideo, a Tai word means a prominent city on the hill ('Che' means a city, 'rai' means prominent and 'doi' means hill). Early name of Charaideo was early name of Charaideo was Bhihagadri Pahar. Earlier Charaideo was under Borahi rulers. Austric King Sunga Saumara was the first ruler of this region. Virochana, Chandrahash, Vikramaditya-Pha, Bicharpati-Pha Pokhra were the Borahi-rulers of this region. The Borahi rulers founded two Capitals close to Charaideo-Sonapur and Banpur. First Ahom ruler Chao-Lung-Siu-Ka-Pha set up the first Capital of Ahom Dynasty here and ruled this area from 1228AD to $1256 \mathrm{AD}$. Charaideo remained the Capital of Ahom Kingdom till the reign of the Ahom King Tyokhamti (1380-1389AD)

\section{Shape of Maidams and Construction:-}

Architecturally it comprises a massive underground vault with a number of chambers having domical superstructure and covered by a heap of earthen mound and externally it appears a hemispherical mound. At the top of the mound, a small open pavilion of bricks is provided which is called "Chow-Chali". An octagonal dwarf wall encloses the whole maidam with pillars of stone and "Coral" in the shape of "Sarai". Coral is a mixture used for cementing which is made with Jaggery, Black gram, straw, fish oil, lime stone, snail's lime etc. The Ahoms preferred to bury the departed family members at Charaideo where the body of the first Ahom Swargadeo (King) Siu-Ka-Pha was laid to rest. The historical Chronicles inform that wives, attendants, Pet-animals and huge quantity of valuables were buried along with the departed Kings. The Maidams of Ahom Kings and queens at Charaideo hillocks are comparable to the pyramids of Egypt and are objects of wonder revealing the excellent architecture and skill of the sculptors and masons of Assam of the medieval period. One of the famous sculptors of Ahom Dynasty was Ghana Shyam Khanikar, who carved out the sculptures on the walls of the tombs like Jaidaud, Rang-Ghar and Kareng-Ghar. Inside the maidams there are a number of chambers which were built for different purposes like-one of the Chambers was for laying the body ofthe departed king which was kept inside an ornamented wooden box called "Rungdang" with all the things needed for the king during life time, the other chambers were for the servants, attendants etc. The soil of the mounds over maidams is very hard, mixed with sulphur and slacked lime. The base of such maidams is octangular and the main entrance is opened to the west. 


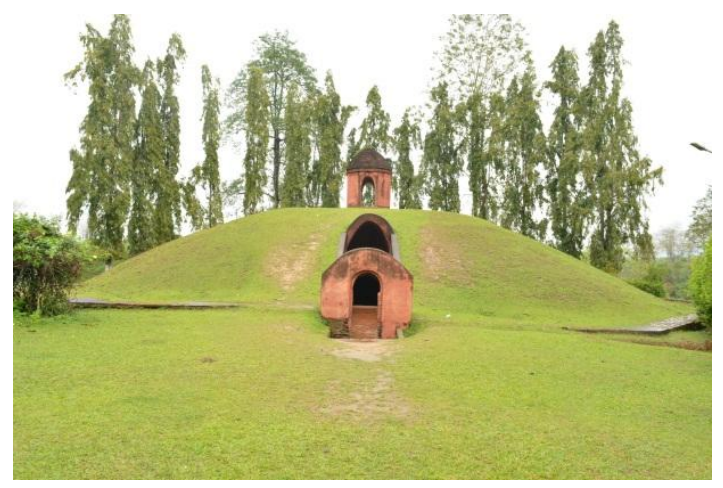

Some of the maidams are two storied and there are three or four chambers in each floor. In the past Shal wood was used for building maidams but later the maidams were constructed with stones and bricks. The ground floor of large maidams spread along two to three acres of land and height of those maidams is about 52 feet. Surrounding each maidam there is octangular boundary wall which is about two to three feet in width and four and half feet high. To build pacca maidams lime stone, Lathia Stone, good quality of bricks and broken bricks were needed. For cementing the bricks and stones Coral was used which was made with Jaggery, black gram, straw, fish-oil, resin, slacked lime, snail's lime etc. According to some historians the maidams were built on plain and then were covered with mound of soil. But others thought that the maidams were raised from beneath the soil and there were underground vaults also. To construct maidams and supply the materials needed, there were definite groups of workers (Khel). The average measurement of most of the large maidams is as follows - Ground floor - length $=231 / 2$ feet, breadth $=12$ feet, width $=4-5$ feet, upper tomb - breadth $=4$ feet, height $=12$ feet. The tomb of the Southern part is $3 \frac{1}{2}$ feet in breadth and height of the top topmost portion from the base of the upper floor is about 30 feet.

Materials needed for construction of maidams:-

To construct the double storied maidam of Swargadeo Shiv Singha the materials needed are listed below :

\begin{tabular}{|c|c|c|c|c|c|c|c|}
\hline $\begin{array}{c}\text { Different } \\
\text { Chambers }\end{array}$ & $\begin{array}{c}\text { Amount of } \\
\text { Jaggery } \\
\text { (Large Picther) }\end{array}$ & $\begin{array}{c}\text { Black } \\
\text { gram } \\
\text { (Dhols) }\end{array}$ & $\begin{array}{c}\text { Straw } \\
\text { (Dhols) }\end{array}$ & $\begin{array}{c}\text { Snail's } \\
\text { lime } \\
\text { (Dhols) }\end{array}$ & $\begin{array}{c}\text { Lathia Stone } \\
\text { (Pieces) }\end{array}$ & $\begin{array}{c}\text { Lime Stone } \\
\text { (Pieces) }\end{array}$ & $\begin{array}{c}\text { Bricks } \\
\text { (Pieces) }\end{array}$ \\
\hline Under Ground & 3220 & 322 & 322 & 4600 & 26000 & 5500 & 570000 \\
\hline Ground floor & 310 & 31 & 31 & 340 & 0 & 1060 & 87360 \\
\hline $\begin{array}{c}\text { Chambers on } \\
\text { ground floor }\end{array}$ & 180 & 18 & 18 & 280 & 0 & 320 & 17100 \\
\hline Base wall & 220 & 22 & 22 & 220 & 46774 & 660 & 191000 \\
\hline $\begin{array}{c}\text { Body of the } \\
\text { Tomb }\end{array}$ & 2600 & 220 & 260 & 2600 & 0 & 7800 & 360000 \\
\hline Total & 6530 & 653 & 653 & 8040 & 72774 & 15340 & 1225460 \\
\hline
\end{tabular}

Note: $\quad$ Pitcher, Dhol etc are traditional units of measurement during Ahom reign. 1 Dhol $=1.57$ quintal (approx) 1 large pitcher $=18$ litre (approx)

In the double storied maidam of Swargadeo (Gadadhar Singha) the materials needed for construction :

\begin{tabular}{|c|c|c|c|c|c|c|c|}
\hline $\begin{array}{c}\text { Different } \\
\text { Chambers }\end{array}$ & $\begin{array}{c}\text { Amount of } \\
\text { Jaggery } \\
\text { (Large Pitcher) }\end{array}$ & $\begin{array}{c}\text { Black gram } \\
\text { (Dhols) }\end{array}$ & $\begin{array}{c}\text { Straw } \\
\text { (Dhols) }\end{array}$ & $\begin{array}{c}\text { Snails lime } \\
\text { (Dhols) }\end{array}$ & $\begin{array}{c}\text { Lathia Stone } \\
\text { (Pieces) }\end{array}$ & $\begin{array}{c}\text { Lime Stone } \\
\text { (Pieces) }\end{array}$ & $\begin{array}{c}\text { Bricks } \\
\text { (Pieces) }\end{array}$ \\
\hline $\begin{array}{c}\text { Ground } \\
\text { floor }\end{array}$ & 5681 & 696 & 635 & 14700 & 125000 & 2600 & 199600 \\
\hline Upper floor & 3606 & 414 & 412 & 9220 & 0 & 6462 & 720630 \\
\hline Total & 9287 & 1110 & 1047 & 23920 & 125000 & 9062 & 1520230 \\
\hline
\end{tabular}

Materials inside Maidam:-

Inside the maidams of Ahom Kings all the materials used by them in their life time were given with the dead body. Besides those, elephants, horses, Caretakers and Servants were also kept in different chambers of the maidams as 
they believed that the king would become alive and live a royal life again. According to Deodhai Buranji, the royal bed of the departed king ornamented with Gold foil and diamond stones was also given inside the maidam. The other necessities of the departed king like pillows embroidered with Golden thread, Hengdang (Sword) of Gold gazed with diamond stones in the handle, Sarai of Silver etc were also given with the dead body. It was found in Deodhai Buranji (puge-144) that earlier at least ten living men were given along with the departed king to take care of him. But this system was later abolished by swargadeo Rudra Singha.

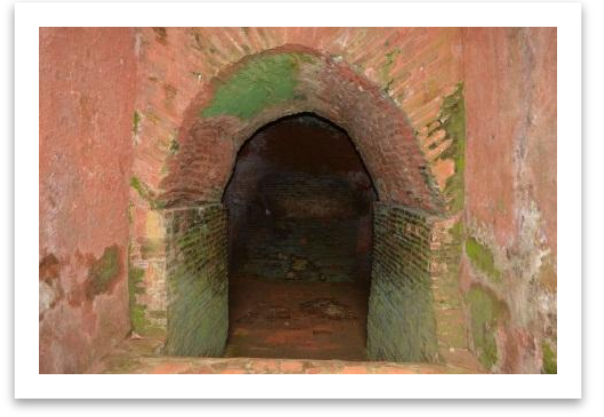

\section{History of Egyptian Pyramids:-}

A pyramid is a structure or monument usually with a quadrilateral base which rises to a triangular point. There are over Seventy pyramids in Egypt stretching down the Nile River Valley. Although largely associated exclusively with Egypt, the pyramid shape was first used in ancient Mesopotamia in the mud-brick structures known as ziggurats. Pyramids are also found in the south of Egypt in the Nubian Kingdom of Meroe. Known as "mir" by the Egyptians, the pyramid was a royal tomb considered the place of ascent for the spirit of the deceased Pharao (kings of ancient Egypt). From the top point of the pyramid it was thought that the soul of the departed king would travel to the after life and could easily return to the earth. The high pinnacle of the pyramid or a life size statue of the departed king on the body of the pyramid served as beacon the soul would recognize. The first pyramid in Egypt is the famous Step pyramid at Saqqara. The design of the pyramid was developed under the reign of Djoser of the Third Dynasty $(2670-2613$ BC)

\section{Construction and Sculpture of pyramids:-}

Djoser's Stp pyramid complex Saqqara was the earliest Construction of its size in world history fully made of stone. Building in stone seems to have been the idea of Imhotep whose inscription appears on the Step Pyramid as chief architect. Imhotep designed the pyramid under Djoser's reign and so the credit for working in stone was divided between Imhotep and his king Djoser. The structure of most of the Egyptian Pyramids is like a glass prism with quadrilateral base and rises to a triangular point.

The pyramid complex was designed to be stunning and inspire awe. When completed, the step pyramid rose 62 metres high and was the tallest structure of its time. The surrounding complex included a temple, court yards, Shrines and living quarters for the priests covering an area of 16 hectares and surrounded by a wall 10.5 meters high. It can be said that the step pyramid complex constitutes a milestone in the evolution of monumental stone architecture in Egypt and in the world as a whole. Here limestone was first used on a large scale as a construction material. The Step Pyramid is a series of mastabas stacked on top of each other, each level a little smaller than the one beneath to form the shape of a pyramid. Earlier mastabas were constructed of clay bricks but the Step Pyramid was made of lime stone blocks on which were carved images of trees and reeds. The actual chambers of the tomb were dug beneath the base as a maze of tunnels with rooms off the corridors to discourage the robbers and protect the body and grave goods of the king. King Djoser's burial chamber was carved of granite stone and to reach it one has to navigate the corridors which were filled with thousands of stone vessels inscribed with the names of earlier kings. The other chambers, in subterranean complex were for ceremonial purposes only for the soul of the Pharaoh. Much experiments were involved which is especially clear in the construction of the pyramid in the centre of the complex. It had several plans with mastaba forms before it became the first Step pyramid in history pilling Six mastaba like levels on top of one another. 


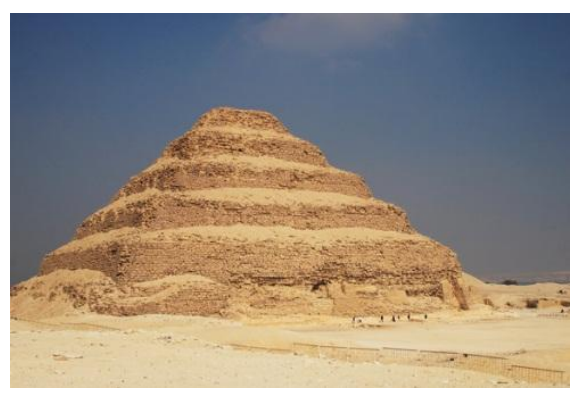

\section{Comparison between Maidams and pyramids:-}

Though architecturally maidams and pyramids are quite different, the ritual belief and custom behind the both is the same. The Ahoms believed that the spirit of the departed king would return to the earth and live a royal life inside the maidams and so they used to keep all the necessities of the king along with the dead body inside the maidams. Even ten to twelve living men were given inside maidam to take care and serve the king.

The Egyptian belief was that the soul consists of nine aspects and one of them the 'ba' (bird shaped image found on the tomb) was able to fly from earth to the heaven at will. It required some recognizable landmark on earth and this would be the pyramid. Once the ba, high above, saw the home of its owner, it could swoop down and enter into its owner. The Statue of Djoser erected at the complex of the Step-Pyramid would have been created for this purpose as well as to remind the living of the legacy of the great king. Similarly on the top of the mound of soil of the maidams a small open pavilion called "Chow-Chali" was provided for the soul of the departed kings to recognize their own home.

Inside of both maidams and pyramids, there are underground chambers or vaults for various purposes like - one of those was for keeping the body of the departed king with all the necessary things to live a royal life and the other chambers were for the servants and care-takers.

The maidams are hemispherical mounds over an octagonal base and the entrance into the vaults inside is to the west of the maidams. But pyramids are like glass prisms in structure with a quadrilateral base which rises to a triangular point.

The heights of the maidams are not as much as the pyramids. But the actual height of the maidams is reduced due to natural calamities, especially due to earthquake and erosion. If the original height of the maidams have remained the same as earlier, these would also have been the "wonders of the world" just like the Egyptian pyramids. Still the height of a few large maidams is almost equal to that of two or three full grown beetel nut tree together.

\section{Woeful conditions of Maidams at present:-}

The actual number of maidams around Charaideo is more that 150 , but only 30 of them are protected by Archeological department. Over 120 maidams remain unprotected. Most of the unprotected maidams have been encroached by the local people or tea-garden owners and so they have already got damaged or dug out. The Bali maidam at Nimona Garh near Charaideo had been dug out and the whole area turned to be a private tea garden. Most of the unprotected maidams had also suffered from robbers and thieves. Some of the maidams were discovered inside the boundary of residents of local people and so they had been dug out in search of precious materials. Assam tea company is also responsible for demolishing the maidams as they had dug out them and plantation was done over the maidams. According to Deo Dhai Buranji, during the attack of Mirjumla many of these maidams were looted. Recently four maidams have newly been discovered near Dalbagan Higher Secondary School, Charaideo inside residential area. Those maidams have already been dug out. During Ahom reign, the maidams were not marked by the name of the departed kings and hence most of the maidams in and around Charaideo could not be indentified properly. The Archeological department of India as well as the Government of Assam has also not given much importance protecting these historical monuments. If special attention had been given for the protection and renovation of the maidams, these would have been recognized as" world heritage" today. 


\section{Conclusion:-}

My principal aim for working in this project is to focus the attention of the world towards the historical importance of maidams of the Ahom-Dynasty which should given as much importance as the pyramids of Egypt. History of maidams is still unknown to most of the people outside Assam and even in Assam also it remains to be a mystery. So, I hope my project would help in spreading the history of maidams and their historical significance.

\section{References:-}

1. "600 years of Ahom Dynasty" written by Sarbananda Rajkumar.

2. "Charaideo" written by Bhuban Chandra Handique.

3. "Deo Dhai Buranji" written by Surya Kumar Bhuiyan

4. "Hathari Akhom Buranji" written by Surjya Kumar Bhuiyan

5. "History of Ancient Egypt" written by Van De Mieroop 